\title{
Reading the Tea Leaves
}

\section{Cindi Bigelow Bigelow Tea}

\section{$T$} he New England Journal of Entrepreneurship was pleased to have the opportunity to meet and discuss current specialty tea trends with Ms. Cindi Bigelow, the third generation in her family to direct the activities of Bigelow Tea, an atypical entrepreneurial American success story. Why atypical? Because the company was the brainchild of Ruth Campbell Bigelow back in 1945, a time when women were in very short supply as entrepreneurs.

\section{NEJE: How well do your remember your grandmother, Ruth? What kind of person was she?}

Bigelow: My grandmother had a very strong personality! College educated women were rare 60 years ago; she was incredibly bright and knew exactly what she wanted and how she wanted it done. The family business was not my grandmother's first entrepreneurial effort, though. Ruth had an interior design business of her own in New York City for more than 20 years before she started Bigelow Tea.

\section{NEJE: What made her switch to tea?}

Bigelow: In the 1930s, during the Great Depression, she lost her business because her clients could no longer afford her services. When my grandmother considered what she should do next, she looked at consumer products that people needed to buy day in and day out-that would be, in effect, depression-proof. However, she shied away from perishables. Ruth wanted something that could last on the shelf and could be shipped or delivered to stores.

\section{NEJE: Why specialty tea?}

Bigelow: My understanding from reading her notes from years ago, is that she really thought it out. Men were being exposed to tea over in Europe during the war, coffee was rationed here in the states, and she felt the market did not have a quality tea. Ruth loved to drink tea, but all the tea imported by the United States was black tea and she had gotten good and tired with "the same old, same old." So she started to experiment in her kitchen with making flavored tea from orange rinds and various spices.

My grandmother served her various tea concoctions to her friends who were suitably impressed. They then asked her to make up batches of her flavored teas for them so they could use the tea at home and also serve it to their friends who came to visit. Word started to get around and Ruth realized she had chanced upon a wonderful niche product. She also sold Chinese spices and tapioca pudding along with the teas because it took awhile for the tea line to catch on. Soon, though, it became clear that tea was where her heart was and where the sales volume would be.

Business grew slowly at first, but with a lot of hard effort, it did grow enough each year to sustain my grandmother's interest. My grandfather was the financial wizard, what we call a "CFO" these days. My father was so talented that my grandmother asked him to help with the fledgling operation after school let out every day.

The two men also served as label makers. Each day, my grandfather with my father by his side, would hand color the front label of each tea container, adding red to the color of the dress for one of the woman drinking tea on the label and adding green to the other woman.

\section{NEJE: Where did the company get its first significant distribution?}

Bigelow: Ruth decided she wanted to be in the premium segment of the tea business, so she solicited orders from Lord \& Taylor's, Bloomingdale's, Macy's, and other upscale department stores in New York. There was some resistance to taking on her line to be sure, but Ruth was not going to be denied. She persisted and persisted until she got a chance to prove herself and her products. Once the stores started to reorder her specialty teas, Ruth never looked back. My grandmother was on a mission!

NEJE: So the first generation of Bigelows started the business and got it off the ground. What did the second generation do?

Bigelow: My father and mother were absolutely instrumental in expanding the product line and obtaining national distribution for the company. They took a small "Mom and Pop" company and made Bigelow into what it is today -an $\$ 80$ million private company that dominates the specialty tea category and is staffed mostly with nonfamily members who are top professionals in their fields. The also expanded the products Bigelow has to offer by getting the company into the flavored honey business as well as flavored coffee.

The business was expanding beyond my grandmother's ability to produce enough product in her kitchen, so the family moved out of New York City 10 years after starting the business in 1945. They set up a small factory operation on Hoyt Street in Norwalk, Connecticut, in the mid-1950s. 
It was considered a godsend to have the production facilities out of the apartment, but it almost proved to be the company's undoing. Terrible floods completely destroyed the building and even though my grandparents were older, they knew they wanted to get back into business as soon as possible, but they weren't sure what should be the first step.

\section{NEJE: Apparently they did.}

Bigelow: Yes, but interestingly, the big push came from their retail accounts. People were so impressed with the quality and honest dealings of the company that they did not want Bigelow to stop production. Several retail accounts loaned money to my grandparents so they could obtain new production facilities, buy the raw materials, and start making tea again. It was truly inspiring.

Today, the company is headquartered in Fairfield, Connecticut, near 1-95 and employs close to 400 people.

\section{NEJE: When did the idea come to put each teabag in a single- foil package?}

Bigelow: That was my dad's idea, probably the most significant contribution ever made to the company. The idea actually came from his desire to get into the food service business. He was trying to figure out a way to allow customers to pick a teabag from a variety of choices, yet maintain freshness and keep the products independent. In his quest to solve this dilemna, he in fact, created our USP (unique selling proposition): foil-overwrapped teabags. This, in turn, made Bigelow different from all the other tea importers and manufacturers. Some, like A\&P, Lipton, and Twinings, were huge operations, and I'm sure they would have liked us to just go away quietly in the night. With my father's concept it would differentiate Bigelow from all the other teas on the supermarket shelf. The decision to buy expensive, complicated machinery that could seal in the product's freshness and keep it sanitary no matter where the product was shipped or stored, was a gutsy and ingenious call on his part. And incredibly brilliant.

NEJE: You credit your dad with the majority of the expansion of the company, but weren't your grandparents a big part of that expansion?

Bigelow: Actually by then it was really more of my dad's show. Dad had made it clear to Ruth that it was time the first generation let go of decision-making and let him take the reins.

NEJE: But you said before Ruth was a real powerhouse. How did she pass the baton?

Bigelow: To be honest, not easily. In fact, my dad left the business for two years because Ruth would not let go. She realized during that period, however, that the company would not have the future she had envisioned for it unless she did let go and allow her son to take over the day-to-day operations of the company. When she came to that conclusion, she invited my father back into the company, but this time with the understanding he would be deciding on the strategic direction of the organization.

NEJE: Now the third generation of Bigelows is in the business, tell us about that and what you hope to contribute.

Bigelow: There are two of us, my sister, Lori, and myself. Lori is incredibly creative and directs our product development group. She is the tea expert and and runs all our $R \& D$. She personally oversees the buying of the raw ingredients for all of our different businesses. I am not sure that kind of personal attention can be found in many businesses today. Lori also works with her team to develop new flavors and has unerringly developed exceptional product line extensions and new products for the company.

I see myself as the "driver" within the company. As a vice president in the marketing and sales area, I am good at seeking opportunities, pulling together ideas from everyone in the company, working to screen for the best ones, and then pulling it all together to make sure things happen. I love working with teams and energizing team members to forge ahead. I quess I would say, I am a movitivator

Lori and I have worked hard to have a real partnership, we really complement each other!

\section{NEJE: And the contribution you want to make?}

Bigelow: Lori and I want to exploit and expand the tea business outside of the supermarket arena. We are not well represented in the health and nutrition store distribution channel; that's something we would like to focus on in the near future.

Long-term, we want to drive down the age skew of our tea drinker demographic. Bigelow and other specialty teas do particularly well with consumers 50 years and older. We want to target the 35 to 49 age group and incite them to drink more tea, then move down through that segment to reach an audience as young as college-age students. 1 believe we will be successful; it's just a matter of time and allocating resources to this effort.

On the product side, we are continually working on new concepts because we ask ourselves: What will be the next "Constant Comment?" What new idea will take us through the next 50 years like "Constant Comment" has the last 50 ? It's tough, it's challenging, it's enervating, and it is what I love about this business. You never know what's coming around the next turn.

\section{NEJE: What's your relationship with your father?}

Bigelow: I don't want to sound trite, but I feel that I could not be more fortunate to have him as my father. I have such tremendous respect for him as a person as well as for 
everything he has done for the company. He, as well as my mother, have given Lori and me a wonderful opportunity to continue growing this amazing organization. I hope to be able to do the same thing for my children one day.

I look forward to working with Lori and putting our own strategic vision in place some day. However, that time has not come yet so we need to try to work things through in the family because, in the end, we all want what's best for the company. It's always a good idea in business, to my way of thinking, to leave your ego at the door. But succession can be a difficult thing to work through. It will take all our efforts.

\section{NEJE: What is the best thing your father did to prepare you for eventually taking over the business?}

Bigelow: I'm glad you asked that question because my dad was exceptional in his thinking about how to involve the third generation in the business. I graduated from college in 1982 and for two years I worked at Seagram's to get an outside perspective on the consumer market.

I joined the company on a part-time basis in 1984 and was charged with conducting a study of the financial area of the organization, looking into how to streamline our processes.. It was an excellent way for me learn how this area of the organization operated, as well as help the company become more efficient.

At the same time, I was a student at the Kellogg School of Management at the Northwestern University where I received my MBA. When I finished in 1986, I joined the company full time where l've been ever since.

\section{NEJE: In the marketing department.}

Bigelow: Hardly. I became a cost accountant and conducted time and motion studies in our manufacturing operation. It was my job to establish costing systems on a PC so that we could update our work processes and make them more efficient.

From there I became part of a three-person team working on business planning and control systems. It forced me to learn what each department did and how it went about its tasks. We implemented an MRP system that tied together manufacturing, purchasing, and sales.

Then I was put in charge of the Purchasing Department. After that stint, I moved over to Customer Service, became Director of Manufacturing, moved to VP of Operations, and then to my current assignment working with our VP, Marketing. It has been a very exciting 15 years with the company!

NEJE: You've received quite an education. In a way, you make it sound like it was easy.

Bigelow: No way! For instance, when I became VP of Operations, I found there was very little teamwork, low morale, and stunning inefficiencies in the way departments worked, or didn't work, with one another. I had one heck of a challenge. There is where I found out I could motivate folks to work together for the common good and make the goal of cutting costs an imperative for everyone to work on. It was a struggle, but this is what "turns me on" every morning. I really enjoy working with others. I love to see things get better, getting to that next level!

\section{NEJE: What would you say to the fourth generation of} Bigelows if your children were here today?

Bigelow: I'd say, first, I see myself, along with my sister, as a custodian for the family business. We have almost 400 employees here in Fairfield and in our other two manufacturing/distribution centers. That means close to 400 families are depending on us to keep their jobs secure for today and in the future. I will not do anything that I believe may jeopardize the responsibility we have for them.

Do we face risks every day? You bet we do. However, I don't seek success for success' sake. I'm not suggesting we would be satisfied with 2 to 3 percent growth each year. I want to hand over a vibrant, growing business to the next generation, but whenever we are faced with making a big decision, I do think about the downside and how careful we have to be to get it right the first time. We don't have the luxury some of our larger competitors have to make some big mistakes, absorb the losses, shrug them off and move on.

NEJE: Since you've inferred Bigelow Tea is a "David" among "Goliaths," do companies like Lipton, Nestlé, Twinings, and Celestial Seasonings even acknowledge that you're in the same business?

Bigelow: (Laughing) Oh, yeah, the big boys know we're around. They have tried more than once to drive us out of business.

\section{NEJE: How?}

Bigelow: By pricing their products so low at retail that profit margins literally are cut to the bone or product is even sold below cost. There's no love lost among us. Our company will never be the first to use the same tactics on our competitors, but, of course, we are forced to react when they threaten our survival. We try not to personalize competitive relationships with those folks, but it can get pretty difficult at times.

\section{NEJE: Who is your toughest competitor?}

Bigelow: Well, they've all held that distinction at one time or another, but I would have to say overall it would be Celestial Seasonings. The founder of the company has seemed to really focus on our company. He looks for ways to compete "off the shelf," if you understand what I mean. That is not how we like to do business. We enjoy good competition but it should be fair-let the consumer decide.

A while ago, one of our competitors sued us for allegedly infringing on their packaging design. We were stunned 
with their charges and knew them to be 100 percent frivolous. However, the legal system requires you to address any charges in court.. So we had to spend, are you ready for this, $\$ 3$ million in legal fees to defend ourselves. That's $\$ 3$ million that could have been spent in product development, upgrading manufacturing capacity, or promoting product to consumers. What a terrible waste. Fortunately for us, after the case was over and the judge read the final verdict, we were completely free of any charges. The judge stated that the charges against us were so ungrounded he actually considered having the company that brought them forward pay our legal fees!

However, on the plus side, we have a "secret" ingredient that will always pretty much guarantee our survival.

\section{NEJE: That is...?}

Bigelow: In a nutshell, my "secret" is actually quite obvious to our consumers. We make a terrific, high-quality product. When you do that, when you pay attention to every facet of your operation, you are going to achieve a loyal following of hard-core, high-frequency buyers. That's our franchise and we are never going to let them down.

NEJE: Do you feel hamstrung by not being a public company? "Going public" would enable you to raise large sums of money to increase your marketing efforts.

Bigelow: No, we prefer staying private. The company has very little debt and over the years, we have forged great relationships with our bankers. If we have to move quickly, we can-and have.

Remaining a private company has the enormous advantage of giving management the opportunity of always keeping their vision on the long-term health of the organization. If we had outside stakeholders, we would be more oriented to think fiscal quarter to quarter. That's the way Wall Street works. So we might be forced to make decisions that could hurt us in the long term, all for the sake of always showing increasing revenue and profits either this quarter to last quarter or this quarter $v$. the same period a year ago. It would distort our strategic planning and change the culture around here.

NEJE: As an entrepreneur, and as a custodian for the family business, can you ever get away from it all, or is this a "24/7" proposition?

Bigelow: l've learned to compartmentalize my life. For women reading this interview, what I have to say will sound very familiar to them. I'm not trying to say anything negative about men, but when my husband (like probably most men) wakes up in the morning, all he has to do is to review his agenda for the day and get himself out of the house. It's not that way for me, and I would guess, probably for most working women in this country. We have several young chil- dren and it's my job to get them up and ready for school each day. Plus, I do a lot of volunteer work at their school and in the community. I have to put my workday world aside so that I can focus on all the other tasks facing me as a mom and as a community-oriented person. That fits the definition of "multitasking," something that women do well and perhaps men could use a little help with.

Oftentimes, I can spend the whole night analyzing and processing information I've received or thinking about how to handle certain situations the next day while l'm trying to sleep. So I wake up exhausted in the morning rather than refreshed. It's tough to keep a balance. That's probably why I do so much volunteer work. It forces me out of the office and helps me understand there's more than just Bigelow Tea in my life.

\section{NEJE: What's the toughest decision you've ever had to make?}

Bigelow: (Pausing) Honestly, I can't think of just one. Each important issue gets dissected, analyzed, processed, and discussed at length. We try not to rush into anything, but approach each critical decision with a lot of analysis and input.

\section{NEJE: What about confrontation? Is that management} style ever necessary?

Bigelow: I don't shy away from confrontation when I feel it is necessary. I've had enough experience to know when it's required and when to back off. From bitter experience, l've learned that if you avoid confrontation, things underneath can get pretty horrible. It's better to get things out in the open than let them fester behind the scenes.

However, having said that, I also want to mention that I've learned never to confront someone else when I feel emotionally attached to the process or the outcome. I wait until I have my emotions under control, then restart the conversation. It hardly means I'm perfect. In fact, every day I find myself reassessing what I could have done better or what I could have said that day that would have led to better communication.

\section{NEJE: Do you ever apologize?}

Bigelow: Oh yes, l'm very good at apologizing! I never hesitate to admit I'm wrong even if I'm not in regular contact with that person. I'll call them up and tell them they were right about something that could have happened weeks or months ago. I can do that because I'm driven to do what is right for the company. It's not about my ego, it's about the success of Bigelow Tea.

NEJE: This may be an unfair question, but do you have a favorite tea flavor? Are you an herbal tea drinker?

Bigelow: Easy to answer. No problem. It's French Vanilla. I love the aroma. All I add is a little milk and sweetener and I'm in heaven. 
NEJE: Do you go to tea parties, a social event that seems to be gaining popularity among professional women, aged 30 and older?

Bigelow: I know about the tea party trend, but my tea parties are at home on weekends. My children love to set the table and prepare the tea for our party. That's the time when mom can sit down with them, relax, talk, laugh, catch up with what's happening in their lives and share some wonderful Bigelow tea.

I'm encouraged by the tea party socials among young, upscale women. That gives me hope we can encourage more and more young people to consider tea as an alternative to coffee.

NEJE: Any suggestions for would-be entrepreneurs? What does it take to be successful?

Bigelow: Boundless energy. A willingness to seek out opportunities and take advantage of them. Don't be afraid of taking risks. Don't get stopped by failures. That's all part of the deal if you want to get to the next level-reach for the stars and fall among the moon.

NEJE: Are today's college students ready to take on the rough and tumble world of entrepreneurship and small business?

Bigelow: I don't see why not. I don't think students today are any less prepared than in my generation or yours, probably they are better prepared in colleges today.

Although it is still difficult to translate what you learn in the classroom with what you have to learn to succeed in the business world, people make that transition all the time. It's a heck of a learning curve, but I believe it is those students that put 100 percent into getting everything they can from school that have the greatest chance for success in the business world. Those college students who just go through the motions during school will find it much more difficult when they mature and enter the competitive world of business.

Attitude, even at a very early age, is everything. 